\title{
Potential antioxidant of brazilian coffee from the region of Cerrado
}

\author{
Richtier Gonçalves da CRUZ ${ }^{1}$, Thais Maria Ferreira de Souza VIEIRA ${ }^{1}$, Simone Possedente de LIRA ${ }^{1 *}$
}

\begin{abstract}
Coffee is one of the most consumed beverages in the world. Its chemical composition may have varied according to the planting site, degree of roasting, and method of preparation. This work aimed to evaluate the antioxidant activity of coffee from the region of Cerrado in the State of Minas Gerais, Brazil. The evaluation was performed with samples roasted at two different levels (traditional and extra dark) and using two different preparation methods (decoction and infusion) that reflect the conditions of preparing coffee. In vitro antioxidant activity by ABTS and DPPH radical methods and the concentration of total phenolic compounds and caffeine were determined. Samples made by decoction showed a higher content of phenolic compounds and no significant difference was observed between the degrees of roasting. However, the antioxidant activity and caffeine concentration of the extra dark samples were higher than those of the traditional samples for both preparation methods. The decoction preparation method was better for extracting phenolic compounds and the extra dark roast showed a higher concentration of caffeine and antioxidant activity. The samples showed a high antioxidant activity, indicating the coffee from Cerrado is an important source of antioxidants.
\end{abstract}

Keywords: decoction; infusion; roasting degree; phenolic compounds; caffeine.

Practical Application: In our study, we used conditions of preparation of the coffee beverage and we tried to establish correlations with the possible ingestion of these compounds in recommended amounts of consumption, comparing different degrees of roasting and methods of preparation. We observed that coffee from the Cerrado region presents as an important source of compounds with antioxidant activity and that the studied variables were significant in different ways in different responses. Being these results pioneering and important for the knowledge and valorization of Brazilian coffee.

\section{Introduction}

Coffee is considered the most important alimentary raw material in the world and is produced extensively in about 60 tropical and subtropical countries (Lashermes et al., 2008; Vieira, 2008). Brazil is the largest coffee producer in the world, accounting for $30 \%$ of the international market, and the second largest coffee consumer, just behind the United States (Brasil, 2014).

The region of Cerrado is located in the northwest of the state of Minas Gerais, which produces 53\% of Brazilian coffee (Ensei, 2010; Associação Brasileira da Indústria de Café, 2014a; Sindicato da Indústria de Café do Estado de Minas Gerais, 2014). This region was a pioneer in implementing the denomination of origin for coffee, indicating that the product has characteristics related with aspects of the geographical environment such as climate, altitude, and soil (Região do Cerrado Mineiro, 2014).

The roasting process involves the application of heat to the beans ranging from 200 to $240{ }^{\circ} \mathrm{C}$ for a period of time that depends on the desired final product. There are three main levels in coffee roasting, light, medium, and dark. The main difference in the process is the time that the coffee remains in the roaster and this process can affect the composition of the coffee indifferent ways (Lerici \& Nicoli, 1990).
The coffee beverage has unique characteristics, which are caused by the partial degradation of phenolic compounds and the development of other bioactive compounds that occur during the roasting process. The antioxidant activity of coffee is produced by components present in the green bean such as chlorogenic acid, and compounds formed during the roasting process such as melanoidins formed by the Maillard reaction (López-Galilea et al., 2006; Santos et al., 2007; Daglia et al., 2008; Babova et al., 2016). Components such as caffeine produce high antioxidant activity and are relatively unaffected during the roasting process (Rodarte et al., 2009; Bicchi et al., 1995). Because of these particularities, the influence of process in the composition of coffee is a subject of interest in many studies.

The antioxidant potential of both coffee beans and beverages has been widely studied. Coffee drink consumption has been associated with several health benefits such as decreased risk of chronic diseases as cancer and diabetes and a reduction of the oxidative damage caused by free radicals (Olthof et al., 2001; Roginsky \& Lissi, 2004; Silva et al., 2007; Stelmach et al., 2015; Oliveira-Neto et al., 2016; Ballesteros et al., 2017). 
In this context, the objective of this work was to determine the influence of roasting levels and preparation methods on the antioxidant activity of Brazilian coffee from the region of Cerrado in the State of Minas Gerais.

\section{Materials and methods}

\subsection{Obtaining coffee samples and preparation of the drink}

Two samples (2 kg each) of roast arabica coffee beans were collected at a company located in the city of São Gotardo, Minas Gerais, Brazil in the region of Cerrado, the first being traditional coffee (medium level of roasting) and the second extra dark coffee (dark level of roasting). Samples were ground to an average particle size (20 mesh), suitable for preparation in a paper filter and espresso machine (Associação Brasileira da Indústria de Café, 2014b).

To prepare the beverage, $12 \mathrm{~g}$ of grounded sample (equivalent to three to four tablespoons) was diluted in one liter of mineral water. Using the method of decoction, water was boiled with the ground coffee until reaching a temperature of $95^{\circ} \mathrm{C}$ and after this was filtrated on filter paper. Using the infusion method, the water was boiled at a temperature of $95{ }^{\circ} \mathrm{C}$ and brought into contact with the ground coffee on the filter paper. After preparing the beverage, the samples were stored in plastic tubes and frozen at $-18{ }^{\circ} \mathrm{C}$ until the moment of analysis.

The four samples of different degrees of roasting and preparation methods were annotated in this way:

CTI: Coffee traditional by infusion;

CTD: Coffee traditional by decoction;

CEI: Coffee extra dark by infusion;

CED: Coffee extra dark by decoction.

\subsection{Determination of phenolic compounds}

The content of phenolic compounds in the beverage was determined by the Folin-Ciocalteu method, using gallic acid as standard (Singleton et al., 1999).

A sample of $20 \mu \mathrm{L}$ of the diluted coffee at a concentration of $1: 20(\mathrm{v} / \mathrm{v})$ was transferred to a test tube and $100 \mu \mathrm{L}$ of the Folin-Ciocalteau solution at $10 \%$ were added to it. After five minutes, $75 \mu \mathrm{L}$ of potassium carbonate solution at $7.5 \%$ were added and the mixture was kept at room temperature and protected from light for 40 minutes. The reading of absorbance was done in the UV-1230 spectrophotometer (Shimadzu UV 1203 model) at $740 \mathrm{~nm}$.

The results were calculated from a standard curve with known concentrations ( 5 to $80 \mu \mathrm{g} \cdot \mathrm{mL}^{-1}$ ) of gallic acid and the results were expressed in $\mathrm{mg}$ of Gallic Acid (GA) per $\mathrm{mL}$ of beverage of coffee and per $100 \mathrm{~g}$ of ground coffee grounds taking into account the preparation of the samples (Al-Duais et al., 2009).

\subsection{Evaluation of antioxidant activity}

\section{Determination by the DPPH radical method}

The antioxidant activity was determined in triplicate using the free radical DPPH (2,2-diphenyl-1-picrylhydrazyl) (Brand-Williams et al., 1995).

In test tubes were added $66 \mu \mathrm{L}$ of the diluted coffee at a concentration of $1: 100$ and $134 \mu \mathrm{L}$ of DPPH radical $0.5 \mathrm{mM}$ diluted in ethanol solution. Then the tubes were stirred and incubated for 45 minutes at room temperature and protected from light. The reading of absorbance was done in UV-1230 spectrophotometer (Shimadzu UV 1203 model) at $517 \mathrm{~nm}$.

The results were calculated from a standard curve with known concentrations (from 0.01 to $0.10 \mu \mathrm{Mol} \cdot 0.5 \mathrm{~mL}^{-1}$ ) of Trolox (6-hydroxy-2,5,7,8-tetramethylchroman-2-carboxylic acid) and expressed as the Trolox equivalent antioxidant capacity ( $\mu \mathrm{Mol}$ of TEAC per $\mathrm{mL}$ of coffee and per $100 \mathrm{~g}$ of ground coffee) (Al-Duais et al., 2009).

Figure 1 shows the stabilization of the DPPH radical by an antioxidant.

\section{Determination by the ABTS radical method}

The antioxidant activity was determined in triplicate using the free radical ABTS (2,2'-azino-bis (3-ethylbenzothiazoline-6-sulphonic acid)) (Re et al., 1999).

The ABTS radical was formed by the reaction of ABTS solution $7 \mathrm{mM}$ with a potassium persulfate solution $140 \mathrm{mM}$, and incubated for 16 hours at room temperature and protected from light. Once formed, the radical was diluted with ethanol $99 \%$ at a concentration of 1:100.

In test tubes were added $20 \mu \mathrm{L}$ of the diluted coffee at a concentration of 1:40 and $220 \mu \mathrm{L}$ of ABTS radical solution. The reading
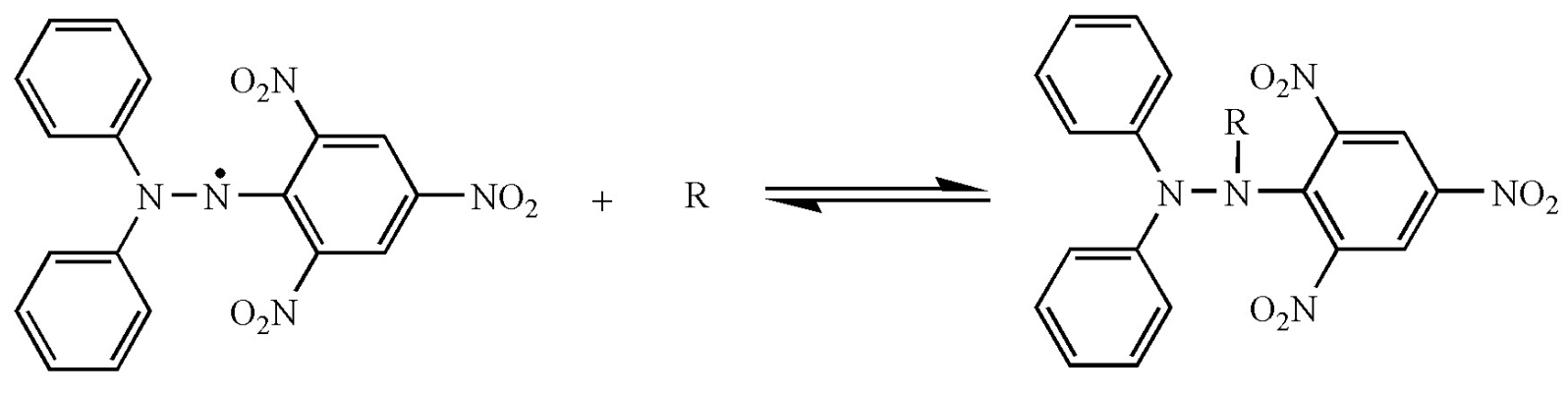

Figure 1. Structure of free and stable DPPH radicals. 


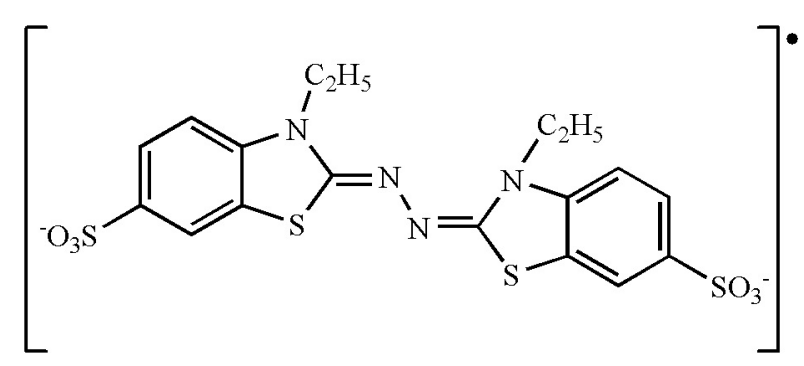

Figure 2. Structure of free and stable ABTS radicals.

of absorbance was done in the UV-1230 spectrophotometer (Shimadzu UV 1203 model) at $730 \mathrm{~nm}$ after six minutes of reaction. The results were calculated from a standard curve with known concentrations (from 0.04 to $0.1 \mu \mathrm{mol} \cdot \mathrm{mL}^{-1}$ ) of Trolox and expressed as the Trolox equivalent antioxidant capacity ( $\mu$ mol of TEAC per $\mathrm{mL}$ of coffee and per $100 \mathrm{~g}$ of ground coffee) (Al-Duais et al., 2009).

Figure 2 shows the stabilization of the ABTS radical by an antioxidant.

\subsection{Quantification of caffeine}

The coffee samples were filtered on a Millipore membrane made of cellulose ester, with $0.45 \mu \mathrm{m}$ pore and a $47 \mathrm{~mm}$ diameter, white, smooth, 100/CX and then diluted in the proportion of 1:50 before being injected into the HPLC. A curve was done with a caffeine standard of 10 to $100 \mathrm{ppm}$. The chromatography was performed on an Agilent HP series 1100 (UV/Vis) with diode array detector (DAD), quaternary pump and a UV detector with a wavelength of multiple waves (MWD), a cooled column compartment $\left(30^{\circ} \mathrm{C}\right)$, and a Phenomenex column $(4.6 \times 250 \mathrm{~mm}-5 \mu \mathrm{m})$. The mobile phase consisted of $20 \%$ of water and $80 \%$ of methanol for 25 minutes and the gradient was isocratic elution. The flow rate was $1 \mathrm{~mL} \cdot \mathrm{min}^{-1}$, the injection volume was $20 \mu \mathrm{L}$. The DAD was set to collect the signal at $254 \mathrm{~nm}$.

\subsection{Statistical analysis}

The experiment was completely randomized with three repetitions and analyses were performed in triplicate. An analysis of variance (ANOVA) and Tukey test were performed at $5 \%$ of significance.

\section{Results and discussion}

Coffee is one of the most consumed drinks in the world, and is known for the presence of several compounds with antioxidant activity. Among the chemical classes responsible for this activity are mainly phenolic compounds, which are considered important antioxidants. These compounds present an aromatic ring bearing one or more hydroxyl groups and their structures may vary from that of the simple phenolic molecule of a complex high-molecular weight polymer. Their mechanism of antioxidant activity is linked with their ability to act as Lewis acids stabilizing free radicals (Balasundram et al., 2006).

The results of total phenolic compounds for the coffee samples are shown in Table 1.
Table 1. Total phenolic compounds of coffee traditional and extra dark subjected to two preparation methods: decoction and infusion.

\begin{tabular}{ccc}
\hline Samples & $\begin{array}{c}\mathrm{mgGA} \cdot \mathrm{mL}^{-1} \text { of } \\
\text { beverage }\end{array}$ & $\begin{array}{c}\mathrm{mgGA} \cdot 100 \mathrm{~g}^{-1} \text { of } \\
\text { ground coffee }\end{array}$ \\
\hline CTD & $1.20 \pm 0.02^{\mathrm{a}}$ & $2946 \pm 3^{\mathrm{a}}$ \\
CTI & $1.00 \pm 0.03^{\mathrm{b}}$ & $2364 \pm 3^{\mathrm{b}}$ \\
CED & $1.10 \pm 0.04^{\mathrm{ab}}$ & $2696 \pm 5^{\mathrm{ab}}$ \\
CEI & $1.00 \pm 0.02^{\mathrm{b}}$ & $2449 \pm 2^{\mathrm{b}}$ \\
\hline
\end{tabular}

Legend: Means followed by different letters in the same column indicate significant differences $(p<0.05)$ by Tukey test. CTD: Coffee Traditional Decoction; CTI: Coffee Tradicional Infusion; CED: Coffee Extra dark Decoction; CEI: Coffee Extra dark Infusion.

The results showed a significant difference $(\mathrm{p}<0.05)$ between the two methods of preparation (decoction and infusion). Traditional coffee prepared by decoction presented a larger amount of total phenolic compounds than the samples prepared by infusion and for extra dark sample the results were higher but not statistically different.

However comparing the amount of total phenolic compounds in the coffee did not change significantly $(p>0.05)$ with different degrees of roasting (traditional and extra dark) using the same preparation method (decoction or infusion).

The traditional coffee submitted to the decoction method had a higher concentration of phenolic compounds in the beverage and grain when compared to the coffees submitted to the infusion method, suggesting that this fact occurred by the contact of the coffee with the water.

Morais et al. (2008) observed that the phenolic compound content in coffee from Cerrado decreased with an increase in the degree of roasting, and the quantity of phenolic compound was higher than the current study reaching values up to $3.000 \mathrm{mgGA} \cdot 100 \mathrm{~g}^{-1}$ of coffee. However, Morais et al. (2008) used an extraction with methanol to conduct the analysis, and this does not reflect the method of preparing coffee in real-world circumstances. This can be a problem because the results can be overestimated when using organic solvents that more readily extract compounds but do not represent the conditions of intake in the real world.

On the other hand. Some studies showed difference in phenolic compound content between different degrees of roasting. It was observed that when comparing the concentration of phenolic compounds in green coffee grains and in dark roasts, there was a linear decrease in total phenolic compounds (Sacchetti et al., 2009). Farah et al. (2005) reported that some phenolic compounds present in coffee, such as chlorogenic acids, 
are degraded into low molecular weight compounds through the roasting process and are partly transformed into quinolactones due to dehydration and the formation of intermolecular bonds.

The coffee is one of the most consumed drinks of the world, studies comparing the influence of decoction and infusion preparation methods were not found in the literature, perhaps because the decoction method is not popular in many countries. Sometimes researchers have not used methods for extracting phenolic compounds that represent the preparation of the beverage.

Traditional coffee, using both methods of preparation (decoction and infusion), presented lower caffeine content $(\mathrm{p}<0.05)$ than the extra-strong coffee, both in the beverage and ground coffee (Table 2).

Caffeine is the main component with psychoactive action in coffee. Among its effects is an increase in cognitive performance, alertness, ability to concentrate, auditory vigilance and visual retention time. It also decreases drowsiness and fatigue and acts as an aid in weight loss due to its thermogenic properties (Nehlig, 2004). The main mechanism of action of caffeine is caused by its structural similarity with the molecule of adenosine (potent endogenous neuromodulator). Thus caffeine can bind to adenosine receptors by blocking them, and the inhibitory action of adenosine is prevented by providing a stimulating effect of caffeine (Biaggioni et al., 1991; Dunwiddie \& Masino, 2001).

Higher degree of roasting produced higher results $(\mathrm{p}<0.05)$ for the samples. Our results were similar to those found by Morais et al. (2008), where the amount of caffeine was around 1.600 to $2.000 \mathrm{mg} \cdot 100 \mathrm{~g}^{-1}$ of ground coffee, and the higher degree of roasting produced more caffeine than light roasting.

Caffeine is a stable molecule when subjected to high temperatures and because of that the concentration is not affected by the roasting process. The lower amounts in the sample with a low degree of roasting can be explained by the fact that caffeine does not stay totally free of coffee structure and when it is submitted to the roasting process, more intense caffeine can be more available to be extracted from the coffee (Monteiro \& Trugo, 2005).

There was no statistical difference $(\mathrm{p}>0.05)$ for the antioxidant activity by the DPPH method for both groups and types of samples (beverage and coffee powder), as described in Table 3. However, by the ABTS method, traditional coffee in both groups Preparation (decoction and infusion) presented lower antioxidant activity $(\mathrm{p}<0.05)$ than extra dark coffee.

Camargo \& Toledo (1998) used the same methodology to prepare the coffee and found a low amount of caffeine when they analyzed 14 brands of Brazilian coffees, concluded that the caffeine concentration can be affected by many factors such as the type of beans and preparation methods, but the authors didn't evaluate coffee from Cerrado.

Several analyses have been used to quantify the antioxidant activity in fresh fruits, vegetables, and others raw foods using radical methods including 2,2'-Azino-bis(3-ethylbenzothia zoline-6-sulfonic acid) (ABTS), diphenyl-1-picrylhydrazyl (DPPH), ferric reducing antioxidant power (FRAP), and oxygen radical absorption capacity (ORAC) (Thaipong et al., 2006; Liang et al., 2016).

$\mathrm{DPPH}$ and $\mathrm{ABTS}$ results presented different results that can be related to the different radical structures applied (Figures 1 and 2). These structures have different types of affinities that involve electrostatic, steric hindrance, and polar interactions among others, which promote different response by several methods of analysis for antioxidant activity, showing the importance of using different methodologies. These results show the importance of utilizing different methodologies to quantify antioxidant activity.

Del Castillo et al. (2002) found an increase in the antioxidant activity of Arabica coffee in the reaction with ABTS in accordance with the degree of roasting when compared with green coffee beans. A higher antioxidant activity in coffee with darker as opposed to lighter roasting was found, and this effect to the increase of products like melanoidins formed during the Maillard reaction in the roasting process (Sánchez-González et al., 2005).

According Nicoli (1998), the formation of melanoidins, which have high antioxidant potential, occurs only at certain stages of roasting which would explain the superiority of antioxidant activity for the sample with a higher degree of roasting. Melanoidins are molecules with important antioxidant activity in coffee and they can represent 25 to $47 \%$ of the total activity depending on the assay used (Perrone et al., 2012). Using the ABTS and DPPH methods melanoidins account for about $40 \%$ of the antioxidant activity, in addition, it has also been

Table 2. Amount of caffeine of coffee traditional and extra dark subjected to two preparation methods: decoction and infusion.

\begin{tabular}{ccc}
\hline Samples & $\begin{array}{c}\mathrm{mg} \text { caffeine } \mathrm{mL}^{-1} \text { of } \\
\text { beverage }\end{array}$ & $\begin{array}{c}\mathrm{mg} \text { caffeine } \cdot 100 \mathrm{~g}^{-1} \text { of } \\
\text { ground coffee }\end{array}$ \\
\hline CTD & $0.70 \pm 0.01^{\mathrm{b}}$ & $1644 \pm 1^{\mathrm{b}}$ \\
CTI & $0.60 \pm 0.02^{\mathrm{c}}$ & $1445 \pm 2^{\mathrm{c}}$ \\
CED & $0.80 \pm 0.01^{\mathrm{a}}$ & $1898 \pm 1^{\mathrm{a}}$ \\
CEI & $0.80 \pm 0.01^{\mathrm{a}}$ & $1879 \pm 1^{\mathrm{a}}$ \\
\hline
\end{tabular}

Legend: Means followed by different letters in the same column indicate significant differences $(p<0.05)$ by Tukey test. CTD: Coffee Traditional Decoction; CTI: Coffee Tradicional Infusion; CED: Coffee Extra dark Decoction; CEI: Coffee Extra dark Infusion.

Table 3. Antioxidant activity of coffee traditional and extra dark subjected to two preparation methods: decoction and infusion, by the DPPH and ABTS method.

\begin{tabular}{ccccc}
\hline Samples & $\begin{array}{c}\mu \mathrm{Mol} \\
\mathrm{TEAC} \cdot \mathrm{mL}^{-1} \\
\text { of beverage } \\
(\mathrm{DPPH})\end{array}$ & $\begin{array}{c}\mu \mathrm{Mol} \\
\mathrm{TEAC} \cdot 100 \mathrm{~g}^{-1} \\
\text { of ground coffee } \\
(\mathrm{DPPH})\end{array}$ & $\begin{array}{c}\mu \mathrm{Mol} \\
\mathrm{TEAC} \cdot \mathrm{mL}^{-1} \\
\text { of beverage } \\
(\mathrm{ABTS})\end{array}$ & $\begin{array}{c}\mu \mathrm{Mol} \\
\mathrm{TEAC} \cdot 100 \mathrm{~g}^{-1} \\
\text { of ground } \\
\text { coffee } \\
(\mathrm{ABTS})\end{array}$ \\
\hline CTD & $7.0 \pm 0.9^{\mathrm{a}}$ & $16633 \pm 9^{\mathrm{a}}$ & $4.4 \pm 0.3^{\mathrm{b}}$ & $10460 \pm 3^{\mathrm{b}}$ \\
CTI & $6.6 \pm 0.7^{\mathrm{a}}$ & $15816 \pm 7^{\mathrm{a}}$ & $6.6 \pm 0.2^{\mathrm{a}}$ & $15816 \pm 2^{\mathrm{a}}$ \\
CED & $5.6 \pm 0.5^{\mathrm{a}}$ & $13345 \pm 6^{\mathrm{a}}$ & $5.7 \pm 0.2^{\mathrm{a}}$ & $13520 \pm 2^{\mathrm{a}}$ \\
CEI & $6.7 \pm 0.9^{\mathrm{a}}$ & $16032 \pm 9^{\mathrm{a}}$ & $5.6 \pm 0.4^{\mathrm{a}}$ & $13309 \pm 4^{\mathrm{a}}$ \\
\hline
\end{tabular}

Legend: Means followed by different letters in the same column indicate significant differences $(\mathrm{p}<0.05)$ by Tukey test. CTD: Coffee Traditional Decoction; CTI: Coffee Tradicional Infusion; CED: Coffee Extra dark Decoction; CEI: Coffee Extra dark Infusion. 
Table 4. Intake of phenolic compounds and equivalents in TEAC and caffeine for the recommended daily amount of coffee.

\begin{tabular}{|c|c|c|c|c|}
\hline Samples & $\mathrm{mg}$ of $\mathrm{GA} \cdot 300 \mathrm{~mL}^{-1}$ & $\begin{array}{c}\mu \mathrm{Mol} \text { TEAC } \\
(\mathrm{DPPH}) \cdot 300 \mathrm{~mL}^{-1}\end{array}$ & $\begin{array}{c}\mu \mathrm{Mol} \text { TEAC } \\
(\mathrm{ABTS}) \cdot 300 \mathrm{~mL}^{-1}\end{array}$ & $\mathrm{mg}$ of caffeine $\cdot 300 \mathrm{~mL}^{-1}$ \\
\hline CTI & $297.8^{\mathrm{b}}$ & $1992.9^{\mathrm{a}}$ & $1437.0^{\mathrm{b}}$ & $182.1^{\mathrm{c}}$ \\
\hline CEI & $308.6^{\mathrm{b}}$ & $2020.0^{\mathrm{a}}$ & $1677.0^{\mathrm{a}}$ & $236.8^{\mathrm{a}}$ \\
\hline
\end{tabular}

Legend: Means followed by different letters in the same column indicate significant differences ( $\mathrm{p}<0.05)$ by Tukey test. CTD: Coffee Traditional Decoction; CTI: Coffee Tradicional Infusion; CED: Coffee Extra dark Decoction; CEI: Coffee Extra dark Infusion.

suggested that chlorogenic acids in green coffee beans produce antioxidants under heat treatment, suggesting that the roasting conditions for coffee play an important role in the formation of antioxidants (Kamiyama et al., 2015).

The daily intake of coffee is divided into three categories, namely low ( $\leq 2$ cups), moderate ( 3 to 4 cups), and high ( $\geq 5$ cups) (Van Woudenbergh et al., 2008). It is considered that a cup contains $75 \mathrm{~mL}$ of coffee; therefore, moderate coffee consumption would be a maximum of $300 \mathrm{~mL}$ per day (in 4 cups).

Moderate coffee consumption ( 3 to 4 cups per day) has shown benefits in preventing cardiovascular disease in men and women from South Korean. This intake was associated with a lower prevalence of subclinical coronary atherosclerosis in a large sample of men and women in South Korea apparently free of clinical evident of cardiovascular disease (Choi et al., 2015).

Table 4 shows the relationship between intake of phenolic compounds and equivalents in TEAC and caffeine for the moderate amount of coffee ( $300 \mathrm{~mL}$ or 4 cups per day).

Coffee is a significant source of compounds with antioxidant activity (Passos et al., 2017) even if there is no ingestion daily intake recommended for these compounds. For example, Falcão et al. (2007) found values ranging from 2.6 to $9.1 \mu \mathrm{Mol}$ TEAC. $\mathrm{g}^{-1}$ (determined by the DPPH and ABTS method) and a total phenolic content raining from 63.4 to $235.4 \mathrm{mg} \mathrm{GAE} \cdot 100 \mathrm{~g}^{-1}$ in grape juice, which is considered an important source of antioxidant compounds.

In addition coffee is considered the most important source of antioxidant compounds in Brazilian's diet when compared with mate, acai and beans. Confirming the importance of this beverage (Torres \& Farah, 2017).

In vitro studies in microsomes, erythrocytes, monocytes, and oxidized LDL designs afforded significant inhibition of lipid peroxidation, mainly to the phenolic compounds like chlorogenic acids and in particular caffeic acid, indicating the coffee drink is a source of natural antioxidants (Smith, 2002).

In our work the results obtained for the antioxidant activity of coffee with two roasting degrees and preparation methods were higher than values for exotic fruits from Brazil considered good sources of antioxidants such as passion fruit, Araça and Jaracatia (Genovese et al., 2008). In addition. The amount of caffeine did not exceed the daily limit $\left(250 \mathrm{mg}^{\text {day }}{ }^{-1}\right)$ indicated by some authors (Grobbee et al., 1990).
Coffee consumption is recommended with a healthy diet and can elicit many health benefits by decreasing the risk of chronic diseases and reducing the oxidative damage caused by free radicals (Olthof et al., 2001; Roginsky \& Lissi, 2004; Silva et al., 2007; Van-Woudenbergh et al., 2008).

\section{Conclusions}

Different degrees of roasting and preparation methods influenced antioxidant properties of the Brazilian coffee from Cerrado. It was conclude that in the conditions of this study the coffee extra dark prepared by decoction had more phenolic compounds and higher antioxidant activity, being this degree of roasting and method of preparation the most indicated in this aspect. Coffee from Cerrado showed high concentrations of these compounds that are proven to be beneficial to human health.

\section{Acknowledgements}

Financial support was provided by FAPESP grant (2014/15760-3), BIOTA/BIOprospecTA FAPESP grant (2013/50228-8). Debec and CAPES BRAFAGRI 022/13 for the technical support.

\section{References}

Al-Duais, M., Müller, L., Böhm, V., \& Jetschke, G. (2009). Antioxidant capacity and total phenolics of Cyphostemma digitatum before and after processing: use of different assays. European Food Research and Technology, 228(5), 813-821. http://dx.doi.org/10.1007/s00217008-0994-8.

Associação Brasileira da Indústria de Café - ABIC. (2014a). Qualidade do café. Rio de Janeiro: ABIC. Retrieved from http://www.abic.com. $\mathrm{br} /$ publique/cgi/cgilua.exe/sys/start.htm?sid=68

Associação Brasileira da Indústria de Café - ABIC. (2014b). Dicas de preparação do café. Rio de Janeiro: ABIC. Retrieved from http:// www.abic.com.br/publique/cgi/cgilua.exe/sys/start.htm?sid=39

Babova, O., Occhipinti, A., \& Maffei, M. E. (2016). Chemical partitioning and antioxidant capacity of green coffee (Coffea arabica and Coffea canephora) of different geographical origin. Phytochemistry, 123(1), 33-39. PMid:26837609. http://dx.doi.org/10.1016/j.phytochem.2016.01.016.

Balasundram, N., Sundram, K., \& Samman, S. (2006). Phenolic compounds in plants and agri-industrial by-products: Antioxidant activity, occurrence, and potential uses. Food Chemistry, 99(1), 191203. http://dx.doi.org/10.1016/j.foodchem.2005.07.042.

Ballesteros, L. F., Ramirez, M. J., Orrego, C. E., Teixeira, J. A., \& Mussatto, S. I. (2017). Optimization of autohydrolysis conditions to extract antioxidant phenolic compounds from spent coffee grounds. Journal of Food Engineering, 199(1), 1-8. http://dx.doi.org/10.1016/j. jfoodeng.2016.11.014. 
Biaggioni, I., Paul, S., Puckett, A., \& Arzubiaga, C. (1991). Caffeine and theophylline as adenosine receptor antagonists in humans. The Journal of Pharmacology and Experimental Therapeutics, 258(2), 588-593. PMid:1865359.

Bicchi, C. P., Binello, A. E., Pellegrino, G. M., \& Vanni, A. C. (1995). Characterization of green and roasted coffes through the chlorogenic acid fraction by HPLC-UV and principal component analysis. Journal of Agricultural and Food Chemistry, 43(6), 1549-1555. http://dx.doi. org/10.1021/jf00054a025.

Brand-Williams, W., Cuvelier, M. E., \& Berset, C. (1995). Use of a free radical method to evaluate antioxidant activity. Food Science and Technology (Campinas), 28(2), 25-30.

Brasil. Secretaria de Produção e Agroenergia. Departamento do Café DCA. (2014). Informe estatístico do café. Brasília: MAPA. Retrieved from http://www.agricultura.gov.br/arq_editor/projecoes $\% 20-\% 20$ versao\%20atualizada.pdf

Camargo, M. C. R., \& Toledo, M. C. F. (1998). Teor de cafeína em cafés brasileiros. Ciência e Tecnologia de Alimentos, 18(4), 101-110. http:// dx.doi.org/10.1590/S0101-20611998000400012.

Choi, Y., Chang, Y., Ryu, S., Cho, J., Rampal, S., Zhang, Y., Ahn, J., Lima, J. A. C., Shin, H., \& Guallar, E. (2015). Coffee consumption and coronary artery calcium in young and middle-aged asymptomatic adults. Heart, 101(9), 686-691. PMid:25732752. http://dx.doi. org/10.1136/heartjnl-2014-306663.

Daglia, M., Papetti, A., Aceti, C., Sordelli, B., Gregotti, C., \& Gazzani, G. (2008). Isolation of high molecular weight components and contribution to the protective activity of coffee against lipid peroxidation in a rat liver microsome system. Journal of Agricultural and Food Chemistry, 56(24), 11653-11660. PMid:19053360. http:// dx.doi.org/10.1021/jf802018c.

Del Castillo, M. D., Ames, J. M., \& Gordon, M. H. (2002). Effect of roasting on the antioxidant activity of coffee brews. Journal of Agricultural and Food Chemistry, 50(13), 3698-3703. PMid:12059145. http://dx.doi.org/10.1021/jf011702q.

Dunwiddie, T. V., \& Masino, S. (2001). The role and regulation of adenosine in the central nervous system. Annual Review of Neuroscience, 24(1), 31-55. PMid:11283304. http://dx.doi.org/10.1146/annurev. neuro.24.1.31.

Ensei, N. (2010). Arabica x Robusta: quando dois mundos se encontram. Café Point. Retrieved from http://www.cafepoint.com.br/noticias/ mercado/arabica-x-robusta-quando-dois-mundos-se-encontram61698n.aspx

Falcão, A. P., Chaves, E. S., Kuskoski, E. M., Fett, R., Falcão, L. D., \& Bordignon-Luiz, M. T. (2007). Índice de polifenóis, antocianinas totais e atividade antioxidante de um sistema modelo de geléia de uvas. Ciência e Tecnologia de Alimentos, 27(3), 637-642. http://dx.doi. org/10.1590/S0101-20612007000300032.

Farah, A., De Paulis, T., Trugo, L. C., \& Martin, P. R. (2005). Effect of roasting on the formation of chlorogenic acid lactones. Journal of Agricultural and Food Chemistry, 53(5), 1505-1513. PMid:15740032. http://dx.doi.org/10.1021/jf048701t.

Genovese, M. I., Pinto, M. D., Gonçalves, A. E. S. S., \& Lajolo, F. M. (2008). Bioactive compounds and antioxidant capacity of exotic fruits and commercial frozen pulps from Brazil. Food Science \& Technology International, 14(3), 207-214. http://dx.doi. org/10.1177/1082013208092151.

Grobbee, D. E., Rimm, E. B., Giovannucci, E., Colditz, G., Stampfer, M., \& Willett, W. (1990). Cofee, caffeine, and cardiovascular disease in men. The New England Journal of Medicine, 323(15), 1026-1032. PMid:2215561.
Kamiyama, M., Moon, J., Jang, H. W., \& Shibamoto, T. (2015). Role of degradation products of chlorogenic acid in the antioxidant activity of roasted coffee. Journal of Agricultural and Food Chemistry, 63(7), 1996-2005. PMid:25658375. http://dx.doi.org/10.1021/jf5060563.

Lashermes, P., Andrade, A. C., \& Etienne, H. (2008). Genomics of coffee, one of the world's largest traded commodities. In P. H. Moore \& R. Ming (Eds.), Genomics of tropical crop plants (pp. 203-225). New York: Springer.

Lerici, C. R., \& Nicoli, M. C. (1990). Il caffè: aspetti chimici, tecnologici e qualità della bevanda. Rivista della Società Italiana di Scienza dell'Alimentazione, 19(1), 1-16.

Liang, N., Lu, X., Hu, Y., \& Kitts, D. D. (2016). Application of attenuated total reflectance-fourier transformed infrared (atr-ftir) spectroscopy to determine the chlorogenic acid isomer profile and antioxidant capacity of coffee beans. Journal of Agricultural and Food Chemistry, 64(3), 681-689. PMid:26725502. http://dx.doi.org/10.1021/acs. jafc.5b05682.

López-Galilea, I., Andueza, S., Leonardo, I., Paz de Peña, M., \& Cid, C.. (2006). Influence of torrefacto roast on antioxidant and prooxidant activity of coffee. Food Chemistry, 94(1), 75-80. http:// dx.doi.org/10.1016/j.foodchem.2004.10.052.

Monteiro, M. C., \& Trugo, L. C. (2005). Determination of bioactive compounds in Brazilian roasted coffees. Quimica Nova, 28(4), 637-641. http://dx.doi.org/10.1590/S0100-40422005000400016.

Morais, S. A. L., Aquino, F. J. T., Nascimento, E. A., Oliveira, G. S., Chang, R., Santos, N. C., \& Rosa, G. M. (2008). Análise de compostos bioativos, grupos ácidos e da atividade antioxidante do café arábica (Coffea arabica) do cerrado e de seus grãos defeituosos (PVA) submetidos a diferentes torras. Ciência e Tecnologia de Alimenos, 28(1), 198-207. http://dx.doi.org/10.1590/S0101-20612008000500031.

Nehlig, A. (2004). Coffee, tea, chocolate, and the brain. Boca Raton: CRC Press.

Nicoli, M. C. (1998). Review of non-enzymatic browning and antioxidant capacity in processed foods. Trends in Food Science \& Technology, 62(1), 425-430.

Oliveira-Neto, J. R., Rezende, S. G., Reis, C. F., Benjamin, S. R., Rocha, M. L., \& Gil, E. L. (2016). Electrochemical behavior and determination of major phenolic antioxidants in selected coffee samples. Food Chemistry, 190(1), 506-512. PMid:26213003. http:// dx.doi.org/10.1016/j.foodchem.2015.05.104.

Olthof, M. R., Hollman, P. C. H., \& Katan, M. B. (2001). Chlorogenic acid and caffeine acid are absorved in humans. The Journal of Nutrition, 131(1), 66-71. PMid:11208940.

Passos, C. P., Kukurová, K., Basil, E., Fernandes, P. A. R., Neto, A., Nunes, F. M., Murkovic, M., Ciesarová, Z., \& Coimbra, M. (2017). Instant coffee as a source of antioxidant-rich and sugar-free coloured compounds for use in bakery: application in biscuits. Food Chemistry, 231(1), 114-121. PMid:28449987. http://dx.doi.org/10.1016/j. foodchem.2017.03.105.

Perrone, D., Farah, A., \& Donangelo, C. M. (2012). Influence of coffee roasting on the incorporation of phenolic compounds into melanoidins and their relationship with antioxidant activity of the brew. Journal of Agricultural and Food Chemistry, 60(17), 4265-4275. PMid:22490054. http://dx.doi.org/10.1021/jf205388x.

Re, R., Pellegrini, N., Proteggente, A., Pannala, A., Yang, M., \& Riceevans, C. (1999). Antioxidant activity applying an improved ABTS radical cation decolorization assay. Free Radical Biology \& Medicine, 26(1), 1231-1237. PMid:10381194. http://dx.doi.org/10.1016/S08915849(98)00315-3. 
Região do Cerrado Mineiro. (2014). Uma região de atitude, para um novo mundo do café. Retrieved from http://cerradomineiro.org/ regiao/a-regiao/

Rodarte, M. P., Abrahão, S. A., Pereira, R. G. F. A., \& Malta, M. R. (2009). Compostos não voláteis em cafés da região Sul de Minas submetidos a diferentes pontos de torração. Ciência e Agrotecnologia, 33(5), 1366-1371. http://dx.doi.org/10.1590/S1413-70542009000500024.

Roginsky, V., \& Lissi, E. A. (2004). Review of methods to determine chain-braking antioxidant activity in food. Food Chemistry, 45(6), 157-177.

Sacchetti, G., Di Mattia, C., Pittia, P., \& Mastrocola, D. (2009). Effect of roasting degree, equivalent thermal effect and coffee type on the radical scavenging activity of coffee brews and their phenolic fraction. Journal of Food Engineering, 90(1), 74-80. http://dx.doi. org/10.1016/j.jfoodeng.2008.06.005.

Sánchez-González, I., Jiménez-Escrig, A., \& Saura-Calixto, F. (2005). In vitro antioxidant activity of coffees brewed using different procedures (Italian, espresso and filter). Food Chemistry, 90(2), 133-139. http:// dx.doi.org/10.1016/j.foodchem.2004.03.037.

Santos, M. H., Batista, B. L., Duarte, S. M. S., Abreu, C. M. P., \& Gouvêa, C. M. C. P. (2007). Influência do processamento e da torrefação sobre a atividade antioxidante do café (Coffea arabica). Quimica Nova, 30(3), 604-610. http://dx.doi.org/10.1590/S0100-40422007000300020.

Silva, D. C. F., Nacimento, M. A., \& Moreira, A. V. B. (2007). Verificação da presença de compostos fenólicos com propriedades antioxidantes em amostras de café. Nutrire, 32(1), 41-58.

Sindicato da Indústria de Café do Estado de Minas Gerais - SINDICAFÉ. (2014). Tipos de café. Belo Horizonte: SINDICAFÉ. Retrieved from http://sindicafe-mg.com.br/plus/modulos/conteudo/?tac=tipos-de-cafe
Singleton, V. L., Orthofer, R., \& Lamuela-Raventós, R. M. (1999). Analysis of total phenols and other oxidation substrates and antioxidants by means of Folin-Ciocalteau reagent. Methods in Enzymology, 299(1), 152-178. http://dx.doi.org/10.1016/S0076-6879(99)99017-1.

Smith, A. P. (2002). Effects of caffeine on human behavior. Food and Chemical Toxicology, 40(9), 1243-1255. PMid:12204388. http:// dx.doi.org/10.1016/S0278-6915(02)00096-0.

Stelmach, E., Pohl, P., \& Szymczycha-Madeja, A. (2015). The content of $\mathrm{Ca}, \mathrm{Cu}, \mathrm{Fe}, \mathrm{Mg}$ and $\mathrm{Mn}$ and antioxidant activity of green coffee brews. Food Chemistry, 182(2), 302-308. PMid:25842341. http:// dx.doi.org/10.1016/j.foodchem.2015.02.105.

Thaipong, K., Boonprakob, U., Crosby, K., Cisneros-Zevallos, L., \& Byrne, D. H. (2006). Comparison of ABTS, DPPH, FRAP, and ORAC assays for estimating antioxidant activity from guava fruit extracts. Food Chemistry, 19(6), 669-675.

Torres, T., \& Farah, A. (2017). Coffee, maté, açaí and beans are the main contributors to the antioxidant capacity of Brazilian's diet. European Journal of Nutrition, 56(4), 1523-1533. PMid:26972079. http://dx.doi.org/10.1007/s00394-016-1198-9.

Van Woudenbergh, G. J., Vliegenthart, R., Van Rooij, F. J., Hofman, A., Oudkerk, M., Witteman, J. C. M., \& Geleijnse, J. M. (2008). Coffee consumption and coronary calcification: the Rotterdam Coronary Calcification Study. Arteriosclerosis, Thrombosis, and Vascular Biology, 28(5), 1018-1023. PMid:18323515. http://dx.doi. org/10.1161/ATVBAHA.107.160457.

Vieira, H. D. (2008). Coffee: the plant and its cultivation. In M. Souza (Ed.), Plant parasitic nematodes of coffee (pp. 3-18). Dordrecht: Springer. 